\title{
CHARLES FEINBERG ON WHITMAN
}

"I think it all began about 1910 when I was eleven years old and going to Ogden School in Toronto. ... Miss McNaughton was a marvelous sixth-grade (senior third in Canada) teacher, and those days, of course, the teacher taught all the subjects. This is the amazing part of it, this is where it started-eleven years old. Miss McNaughton used to read to us. She had a book called American Poems, published in England, I think, about 1872 by Edward Moxon. The editor was William Michael Rossetti - which meant nothing to me at that time. It included Longfellow, Whittier, Lowell, Poe, Whitman, many others; but it was dedicated to Walt Whitman, and I remember ... I went to her and asked the meaning of the word 'dedication,' and she told me to look it up in the dictionary. I didn't know about dictionaries - she introduced me to them. Every Friday afternoon Miss McNaughton would include a period during which we would read poetry and a pupil would be assigned a poem to recite the following week-she once gave me such an assignment from American Poems. It's hard to remember why you are stopped by a word or a line or a page, but that was the beginning of my interest in Walt Whitman." (Matthew J. Bruccoli, ed., Pages [Detroit: Gale Research, 1976], 1:274)

"Whitman had friends who became collectors of his writings, while other Whitman collectors became his friends. The collectors may not have been gifted with the creative sense; or if they had it, they may have lacked the ability to translate that sense into the work of a Whitman. However, through the preservation of the manuscripts, letters, books, and other material, they did much to enhance and ennoble the illumination of Whitman's great creativity. Whitman himself formed the foundations of such collections by building the most extensive of them. He hopefully believed he would continue to be read, by people in foreign countries as well as by Americans, and that his writings would acquire a degree of literary importance. He preserved much of his early poetry and prose in addition to his correspondence. Fortunately for collectors and literary historians, this early habit continued throughout his life. He kept drafts of letters, bills regarding publication matters, memoranda of events in his literary and personal life, and notebooks of ideas for future poetry and prose writings.... He gave away many manuscript items to friends and admirers. $\mathrm{He}$ liked to feel that a little bit of himself was included when he sent a manuscript along with a letter, a book or a newspaper... . Because of the large and diverse amount of material available, today's collector of Whitman is privileged, through his interest, in effect to know Whitman, a man whose life and times were so much different from our own, and yet a man who becomes as well known as one's own friend." (Walt Whitman: A Catalogue Based Upon the Collections of the Library of Congress [Washington: Library of Congress, 1955], vi)

"There has always been an air of mystery about some of the early years of Walt Whitman, particularly those preceding the publication of Leaves of Grass in 1855. Whitman, himself, passed over these years quickly and inaccurately... These years have been years in which biographers of Whitman have not had available very much factual information and, in most cases, have glossed over very quickly. During this time when Whitman was involved with his businesses and work on newspapers, he was also gathering material and writing on the history of the City of Brooklyn, which 
he started about 1850 . And, of course, he was writing trial lines of poetry. These years are important years because they led to his writing Leaves of Grass. . . . Some biographers have treated Whitman as a careless idler, a drifter, a loafing dreamer, who never took his meals on time and worked only when he felt like it. What I have tried to say is that Whitman was a very practical young man, devoted to his family, making money to support them and being modestly successful in business matters. By 1855 , he felt that he was ready to publish his Leaves of Grass and deliberately turned his back on all of his money-making ventures, to do what he felt he was born to do, to be a writer, the poet and singer of America's songs, the architect of the American Dream." (The Papers of the Bibliographic Society of America, 52 [1958], 73-92)

"To me Whitman sang of a new land, in a new way. He sang the love of comrades, of one brotherhood throughout the wide world. Whitman sang of freedom in a new world and found his inspiration in people and life around him, what his eyes saw, what his ears heard, what his heart felt, what his head reasoned. He sang of things here. He was himself. Today a great part of American writing is actually American because of Whitman's pioneer work." (Walt Whitman: A Selection of the Manuscripts, Books and Association Items [Detroit: Detroit Public Library, 1955], xi) 